\title{
Studies of heavy metal content in bottom sediments and aquatic plants near treated wastewater discharge
}

\author{
Mirosław Skorbiłowicz, Elżbieta Skorbiłowicz, Urszula Tarasiuk, \\ Mariola Falkowska
}

Bialystok University of Technology, Faculty of Building and Environmental Engineering; ul.Wiejska 45E, 15-351 Białystok, Poland; e-mail: m.skorbilowicz@pb.edu.pl

\begin{abstract}
(C) 2017 Authors. This is an open access publication, which can be used, distributed and reproduced in any medium according
\end{abstract} to the Creative Commons CC-BY 4.0 License requiring that the original work has been properly cited.

Received: 12 December 2017; accepted: 18 January 2018

\begin{abstract}
The paper attempts to determine the degree of impact of discharged wastewater from five treatment plants on the Bug River ecosystem and its inflow, the Kamianka. For laboratory tests, samples of bottom sediments and aquatic plants were collected in 2014. The content of heavy metals: $\mathrm{Zn}, \mathrm{Pb}$, Ni in bottom sediments and aquatic plants (root, stem, leaf) growing close to the discharge of purified sewage, were analyzed. The amount of metals in the samples was determined applying the AAS method in its flame version. The average content of the metals determined in bottom sediments from the study points located before the treatment plant were $\mathrm{Zn}-21.8 ; \mathrm{Pb}-11.5 ; \mathrm{Ni}-13.7 \mathrm{mg} \cdot \mathrm{kg}^{-1}$. However, the content of these metals was higher in samples from the collection points which were located after the place of purified sewage discharge and amounted to: $\mathrm{Zn}-34.3 ; \mathrm{Pb}-12.2$; $\mathrm{Ni}-16.9 \mathrm{mg} \cdot \mathrm{kg}^{-1}$. The test plants were Acorus calamus L., Nuphar lutea L., Typha angustifolia L. The content of metals in the individual parts of macrophytes (root, stem, leaf) was as follows: $\mathrm{Zn}>\mathrm{Pb}>\mathrm{Ni}$. In the bottom sediments and aquatic plants of the Bug and Kamianka rivers, a higher content of lead, zinc and nickel was found after the discharge of treated sewage in relation to their content than before discharge, but it was not a threat to the aquatic environment of the watercourses studied. Statistical analysis showed that the amount of sewage discharged to the tested receivers influenced the content of organic matter, zinc and nickel in bottom sediments.
\end{abstract}

Keywords: rivers, wastewater treatment plant, metals, bottom sediment, macrophytes

\section{INTRODUCTION}

Increased heavy metal content in an aquatic environment is the result of, among other things, the discharge of sewage from industrial production, the mining and processing of mineral raw materials, the functioning of cities and water transport (Donahue et al. 2000, Brack et al. 2001, Lindström 2001a, 2001b, Mecray et al. 2001). As a result of the continuous increase of heavy metal content in the natural environment, they are considered a global problem due to their properties, i.e. non-biodegradable, toxic and bio-accumulation properties, which leads to potential long-term consequences for the ecosystem and human health (Banerjee \& Gupta 2013, Dou et al. 2013, Raza et al. 2016).

Bottom sediments are good indicators of the degree of river environment pollution (Nocoń 2006, Kucuksezgin et al. 2008, Essien et al. 2009), and contamination of aquatic sediments is one of the main environmental problems due to their potentially negative impact on biological resources and, indirectly, on human health. Sediments are a store for the majority of potentially toxic substances that reach both rivers and lakes (Skorbiłowicz 2012) and therefore, due to the higher concentration of contaminants in comparison to their content in water, they are an important 
indicator in the study of environmental pollution (Banach \& Chlost 2005, Wang et al. 2014, Xu et al. 2014).

In aquatic ecosystems, heavy metals occur not only in bottom sediments, but also in plants and animals. The accumulation of metals by macrophytes depends on the concentration of a given metal in water and sediments (Lin \& Zhang 1990). According to Albers \& Camardese (1993), the content of heavy metals in macrophytes can be up to 100,000 times higher than their amount in water. Aquatic plants are often used to monitor the content of heavy metals and pesticides in the aquatic environment (Klumpp et al. 2002).

The area covered by the research is situated in the central part of the Bug River catchment (Podlaskie province - 3 sewage treatment plants and Lubelskie province -2 treatment plants). This region is only slightly affected by man and the main sources of pollution on the analyzed section of the river are treated municipal sewage and, to a small extent, industrial wastewater. The paper attempts to determine the degree of impact of discharged treated wastewater from five treatment plants on the Bug River ecosystem and its inflow, the Kamianka. The content of metals $(\mathrm{Pb}, \mathrm{Zn}, \mathrm{Ni})$ in bottom sediments and aquatic plants (root, stem, leaf) near the discharge of treated wastewater was analyzed.

\section{METHODS}

\section{Study area}

The Bug River catchment is located in north-west Ukraine, south-west Belarus and central-eastern Poland. The total length of the Bug River (from springs in Ukraine to the Zegrzyński Zalew) is $755 \mathrm{~km}$, including almost $185 \mathrm{~km}$ in Ukraine and the catchment area in Poland is $39.420 \mathrm{~km}^{2}$, with the Bug River being the fourth largest river in Poland. The Kamianka River is the right tributary of Bug with a total length of $23.41 \mathrm{~km}$, and its catchment area is $127.2 \mathrm{~km}^{2}$. The Kamianka River is a receiver of wastewater discharged from the municipal sewage treatment plant in Siemiatycze. The area covered by the research is in Podlasie province in the Siemiatycze district (the sewage treatment plants in Siemiatycze, Drohiczyn and Mielnik) and in Lubelskie province, Bialskie commune (the purification plant in Terespol) and Włodawa commune (the wastewater treatment plant in Włodawa).

The analyzed treatment plants and sampling points for bottom sediments and aquatic plants are presented in Figure 1. The wastewater treatment plant in Włodawa is a mechanical and biological treatment plant and sewage is directed to the sewage treatment plant by a common gravitational collector delivering household sewage to the catchment point, as well as sewage from slurry tankers. Wastewater from the meat and tanning industry is supplied to this treatment plant, as well as municipal sewage from the village and municipal commune of Włodawa, as well as sewage from the auxiliary unit of the commune (village): Szuminka and Suszno and sewage managed by the Jezioro Białe Water and Sewage Company from the villages of Okuninka and Orchówek. The average daily flow of the treatment plant in Włodawa currently amounts to $4.800 \mathrm{~m}^{3} \cdot \mathrm{d}^{-1}$, although in practice the amount of incoming sewage to the treatment plant varies from $2.015 \mathrm{~m}^{3} \cdot \mathrm{d}^{-1}$ to $2.694 \mathrm{~m}^{3} \cdot \mathrm{d}^{-1}$. The treated wastewater is discharged into the Bug River.

The sewage treatment plant located in Terespol is a mechanical and biological treatment plant, to which sewage is supplied due to sanitary sewage (pressure and gravity) that drains the sewage from 645 residential buildings, and is also transported by slurry tankers. The discussed sewage treatment plant also removes pollutants from the transport sewage, industrial plants, as well as technological and sanitary sewage from the area. The average daily capacity of the Municipal Sewage Treatment Plant in Terespol reaches $1000 \mathrm{~m}^{3} \cdot \mathrm{d}^{-1}$, while in practice the amount of incoming sewage into the treatment plant is $400 \mathrm{~m}^{3} \cdot \mathrm{d}^{-1}$. Wastewater after treatment is discharged into the Bug River.

The sewage treatment plant located in Mielnik is a mechanical and biological treatment plant of the SBR type, to which sewage is supplied from the sanitary sewage system and sanitation vehicles. The capacity of the treatment plant is $Q_{\mathrm{av}}=230 \mathrm{~m}^{3} \cdot \mathrm{d}^{-1}$. Treated wastewater is discharged into the Bug River.

The wastewater treatment plant located in Drohiczyn is a mechanical and biological treatment plant used only by the inhabitants of this city. The average daily sewage inflow is $Q_{a v}=330 \mathrm{~m}^{3} \cdot \mathrm{d}^{-1}$. Treated wastewater is discharged into the Bug River. 


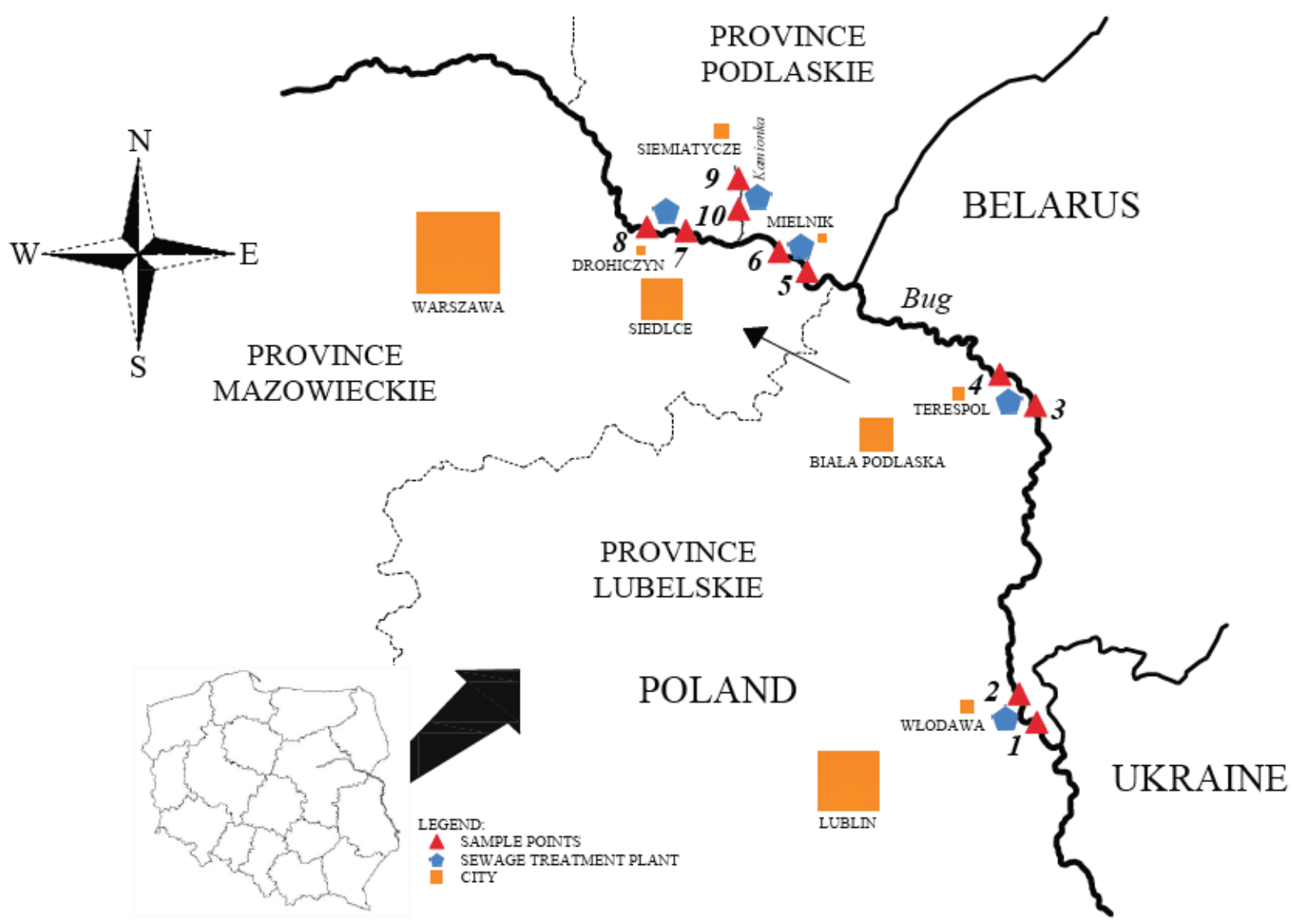

Fig. 1. The analyzed treatment plants and sampling points for bottom sediments and aquatic plants

The wastewater treatment plant in Siemiatycze is a mechanical and biological treatment plant with enhanced nutrient elimination. It purifies the sewage that reaches the sewage treatment plant by slurry tanker, as well as via the sanitary sewage system. Currently, about $56 \%$ of Siemiatycze's residents use the sanitary sewerage system. The discussed sewage treatment plant also removes impurities from industrial wastewater from dairy and fruit and vegetable processing. The average daily capacity of the treatment plant is $4.730 \mathrm{~m}^{3} \cdot \mathrm{d}^{-1}$; in practice, the amount of incoming sewage to the treatment plant varies from $3.800 \mathrm{~m}^{3} \cdot \mathrm{d}^{-1}$ to $4.200 \mathrm{~m}^{3} \cdot \mathrm{d}^{-1}$. Treated wastewater is discharged into the Kamianka River.

\section{Analysis}

In order to determine the content of heavy metals in bottom sediments and macrophytes near the treated wastewater discharge sites, the following measurement points were located in: Włodawa 1,2,
Terespol 3, 4, Mielnik 5, 6, Drohiczyn 7, 8, and Siemiatycze 9, 10 (Fig. 1). Samples of bottom sediment and aquatic plants for laboratory analyses were collected in 2014 about $60 \mathrm{~m}$ before and after the treated sewage discharge site on the Bug River and $20 \mathrm{~m}$ before and after the treated sewage discharge site on the Kamionka River. Bottom sediment samples were collected from sites where no other interaction sources were found near the purified wastewater collectors. According to Bielski (2012), to show a potential environmental change in bottom sediments due to the sewage discharge from the treatment plant, it is advisable to perform studies on undeveloped watercourse sections. Further fragments of studied rivers are altered by other tributaries to such a degree that any study would not provide the opportunity to assess environmental changes due to wastewater discharge, because the contaminant load in tributaries predominates. Rutherford (1994) claims that, in fact, the complete mixing of the wastewater 
within a short distance from the discharge is incidental. Determining the distance of full mixing should be considered on a given river inter-section - both vertical and cross-section. Based on studies on the self-cleaning process of the Juma River in China, it was found that mixing the water with purified sewage depends mainly on the volume and flow rate of river water, bottom sediment load and the presence of aquatic vegetation (Tian et al. 2011). Solutions based on the morphological parameters of aquatic objects (among others, river bed width) are often applied to determine the size of the mixing zone. In many European countries, mixing zones are determined by means of river width (Skorbiłowicz et al. 2017).

Bottom sediments were collected from the river bank, where suspended material is precipitated (Bojakowska 2001). Several single samples of surface bottom sediments were collected at each selected measurement point from a depth of 5-10 $\mathrm{cm}$ beneath the water surface. After homogenizing the material, representative samples of about $1000 \mathrm{~g}$ were obtained and samples were then air-dried and stored before determination (Lis \& Pasieczna, 1995). Before analyses, bottom sediment samples were dried at $40^{\circ} \mathrm{C}$ and sieved through $200 \mu \mathrm{m}$ mesh. According to Förstner \& Wittmann (1981), fractions between 20-200 $\mu \mathrm{m}$ grain size are suitable for the evaluation of the contamination impact. They are a representative majority in sediment and therefore determine the transport of toxic substances. The selection of $<200 \mu \mathrm{m}$ was also dictated by the possibility of comparing the achieved results with the geochemical monitoring of Polish aquatic sediments. Bottom sediments were digested in hydrochloric and nitric acids at a 3:1 ratio in a CEM hermetic microwave system. All determinations were made in triplicate. The content of metals in the bottom sediments were analyzed by applying an AAS ICE 3500 Thermo Scientific atomic absorption spectrometer. The results were verified using certified reference material NCS DC 73317a (Tab. 1). The content of organic matter was specified based on the weight difference of samples before and after being burned at $450^{\circ} \mathrm{C}$. Sediment was analyzed using the potentiometric method.

The results of metal content obtained were expressed relative to the air-dried sediments and compared to literature data. In addition, the average quantity of metals from analyzed measurement points was compared with the arithmetic mean for these metals in bottom sediments for Poland (Lis \& Pasieczna 1995). To assess the degree of sediment contamination with heavy metals, the classification of aquatic sediments in Poland based on geochemical criteria was used (Bojakowska \& Sokołowska 1998) as well as threshold values taking into account the harmful impact of contaminants accumulated in sediments on aquatic organisms (Bojakowska 2001). The geo-accumulation index $\left(I_{g e o}\right)$ was calculated using (Müller 1979):

$I_{\text {geo }}=\log _{2}\left(\frac{C_{m}}{1.5 \mathrm{GM}}\right)$

where:

$C_{m}$ - content of the analyzed metal $\left[\mathrm{mg} \cdot \mathrm{kg}^{-1}\right]$, GM - geochemical background [mg. $\left.\mathrm{kg}^{-1}\right]$.

In terms of the geochemical background, the average content in shales was assumed $\left[\mathrm{mg} \cdot \mathrm{kg}^{-1}\right]$ : $\mathrm{Zn}-95, \mathrm{~Pb}-20, \mathrm{Ni}-68$ (Turekian \& Wedepohl 1961).

Table 1

Results of the validation of the test method used

\begin{tabular}{|c|c|c|c|c|}
\hline Specification & Unit & $\mathbf{P b}$ & $\mathrm{Cr}$ & Zn \\
\hline Wavelength & {$[\mathrm{nm}]$} & 217.0 & 357.9 & 213.9 \\
\hline Content in the certified reference material NCS DC 73317a. & \multirow{6}{*}[\mathrm{mg}\cdot\mathrm{kg}^{-1}]{} & 555 & 43 & 780 \\
\hline Measured content in reference material NCS DC 73317a & & 549 & 42 & 775 \\
\hline Content in the certified reference material ERM - CD281 & & 1.67 & 24.8 & 30.5 \\
\hline Measured content in reference material ERM - CD281 & & 1.60 & 24.3 & 29.9 \\
\hline Content in the certified reference material LGC7162 & & 1.8 & 2.15 & 24 \\
\hline Measured content in reference material LGC7162 & & 1.9 & 2.09 & 23 \\
\hline
\end{tabular}


The $I_{g e o}$ value distinguishes seven classes: non-contaminated sediment - class $0\left(I_{\text {geo }} \leq 0\right)$, weakly contaminated sediment - class 1 $\left(0<I_{\text {geo }}<1\right)$, moderately contaminated sediment class $2\left(1<I_{g e o}<2\right)$, averagely contaminated sediment - class $3\left(2<I_{\text {geo }}<3\right)$, strongly contaminated sediment - class $4\left(3<I_{g e o}<4\right)$, very strongly contaminated sediment - class $5\left(4<I_{\text {geo }}<5\right)$, extremely contaminated sediment - class $6\left(I_{\text {geo }} \geq 5\right)$.

Each test plant sample (Tab. 2) was composed of at least ten single sub-samples (Djingova et al. 2004). After delivery to the lab, the collected roots, stems, and leaves were very thoroughly washed with tap water and then distilled water. They were then dried to a constant weight at $80^{\circ} \mathrm{C}$. After drying, samples of roots, stems, and leaves were homogenized and digested in a CEM microwave system in a mixture of hydrochloric and nitric acids at high temperature and pressure, according to the CEM method. The content of heavy metals was determined by means of the AAS technique. The correctness of the method was verified by comparing the achieved results with the characteristics of two plant certified reference materials: grass mixture - ERM - CD281 and strawberry leaves - LGC7162). Calculated measurement error did not exceed $5 \%$ of certified value.

The obtained results of the studied metals content were expressed in reference to the dry matter of plants and compared to literature data also for dry matter. The physiological norm of metal content for plants was given according to
Kabata-Pendias \& Pendias (1999) and Markert (1992). The result analysis included the calculation of the bio-concentration coefficient expressed as a ratio of the metal content in a plant root to the metal concentration in bottom sediment, as well as the enrichment index that was expressed by the ratio of metal content in stems and leaves to that in sediment.

Basic statistics including arithmetic mean, standard deviation $( \pm)$, median, maximum and minimum were given for the obtained results. Before statistical analysis, the distribution compatibility of the investigated metals in bottom sediments, water plants, as well as sediment characteristics and the amount of sewage discharge with normal distribution at $p=0.05$ level was checked. Most metals in sediments and aquatic plants, as well as sediment characteristics, were compatible with the normal distribution. However, there was no compatibility with normal distributions and the amount of sewage discharge. The correlation between $\mathrm{Pb}, \mathrm{Zn}$ and $\mathrm{Ni}$ content in sediments, its characteristics and parts of plants (root, stem, leaf) was assessed with Pearson's $(r)$ parametric correlation test. The correlation between wastewater amounts and the metal content in sediments and aquatic plant parts was tested using the nonparametric Spearman's rang correlation test. Spearman's correlation was also used due to the number of variables (amount of wastewater) taken for analysis. Statistical calculations were made with the use of the Statistica 13.1 program.

Table 2

List and description of the macrophyte species collected from ten sample points on Bug River (Szoszkiewicz et al. 2010)

\begin{tabular}{|l|l|l|}
\hline \multicolumn{1}{|c|}{ Sites } & \multicolumn{1}{c|}{ Plant type } & \multicolumn{1}{c|}{ Species } \\
\hline $1,2,3,4,5,6$ & $\begin{array}{l}\text { Acorus calamus L. is common throughout Poland except in mountain } \\
\text { areas, it can be found in swamps, wet meadows, marsh areas, ditches } \\
\text { and on the banks of rivers and lakes }\end{array}$ & Acorus calamus L. \\
\hline 9,10 & $\begin{array}{l}\text { Nuphar lutea in Poland occurs mainly in lowland areas where it is } \\
\text { a common plant. It grows in river waters which are abundant in organic } \\
\text { substances at a depth of 50 to } 200 \mathrm{~cm} \text {, as well as in places where the } \\
\text { bottom of the riverbed is sandy-silty or muddy }\end{array}$ & Nuphar lutea \\
\hline 7,8 & $\begin{array}{l}\text { Typha angustifolia } \mathrm{L} \text {. in Poland it appears in lowland areas, but rare in } \\
\text { mountain ones. It grows at a depth of up to } 1.5 \text { m in slow-flowing rivers, } \\
\text { and in stagnant waters, it is also found in ditches on sandy or loamy } \\
\text { substrates. The plant develops only in areas where its rhizomes and } \\
\text { roots are constantly immersed in water }\end{array}$ & Typha angustifolia L. \\
\hline
\end{tabular}




\section{RESULTS AND DISCUSION}

An important factor that determines the adsorption of metals is sediment grain-size distribution. Fine particles with a larger surface area to molecular weight ratio will have better adsorption capability than larger particles with a smaller surface area. Coarse-grained sediments in sandy fractions may also contain high concentrations of metals, which is a result of the presence of heavy minerals (Ciszewski \& Aleksander-Kwaterczak 2015). The analyzed bottom sediments had a loose sand and light loamy sand nature. The presence of organic matter in bottom sediments played an advantageous role in retaining the contaminants due to the sorption capacity. According to $\mathrm{Hu}$ et al. (2013), the amount of organic substances in sediments can be a good indicator of metal bio-availability and their mobility due to their affinity with heavy metals. The content of organic matter (OM) in sediments varied and ranged between $1.4-24.0 \%$. The lowest content of organic matter was found at the measurement points 3 and 4 (Terespol), while the highest was in bottom sediments originating from points 5 and 6 (Mielnik). Probably the presence of forest in the catchment is the source of the allochthonous-origin the organic matter precipitated in bottom sediments near these points. The content of the organic matter behind the treated wastewater discharge was higher, indicating an accumulation of organic matter in sediments, the source of which could be insufficiently treated sewage. The exception was the treatment plant in Włodawa (Tab. 3). The pH of the sediments from the Bug River ranged between $6.77-7.36 \mathrm{pH}$, while those from the Kamianka River were between 6.53-6.94 pH. It was found that discharged purified wastewater contributes to a decrease in bottom sediment $\mathrm{pH}$. For all of the studied points, the $\mathrm{pH}$ of sediments after the treated sewage discharge was lower, indicating the interaction of purified wastewater with the aquatic environment of rivers.

Table 3

Content of heavy metals, $\mathrm{pH}$ and organic matter in the bottom sediments of the Bug and Kamianka rivers

\begin{tabular}{|c|c|c|c|c|c|c|c|c|}
\hline \multirow[t]{2}{*}{ River } & \multicolumn{3}{|c|}{ Measurement points } & \multirow{3}{*}{$\begin{array}{c}\text { pH } \\
7.06\end{array}$} & \multirow{3}{*}{$\begin{array}{c}\text { Organic substance } \\
\text { content [\%] } \\
6.40\end{array}$} & \multicolumn{3}{|c|}{$\begin{array}{l}\text { Heavy metals content } \\
{\left[\mathrm{mg} \cdot \mathrm{kg}^{-1}\right]}\end{array}$} \\
\hline & & & & & & \multirow{2}{*}{\begin{tabular}{c|}
$\mathbf{P b}$ \\
10.83
\end{tabular}} & \multirow{2}{*}{$\begin{array}{c}\mathbf{Z n} \\
23.16\end{array}$} & \multirow{2}{*}{$\begin{array}{c}\mathrm{Ni} \\
16.65\end{array}$} \\
\hline \multirow{8}{*}{ River Bug } & 1 & \multirow{2}{*}{ Włodawa } & before & & & & & \\
\hline & 2 & & behind & 6.87 & 6.00 & 10.94 & 45.12 & 21.10 \\
\hline & 3 & \multirow{2}{*}{ Terespol } & before & 7.36 & 1.40 & 11.78 & 18.84 & 12.70 \\
\hline & 4 & & behind & 6.89 & 1.80 & 13.02 & 19.80 & 12.95 \\
\hline & 5 & \multirow{2}{*}{ Mielnik } & before & 7.24 & 21.40 & 10.45 & 27.15 & 15.60 \\
\hline & 6 & & behind & 6.81 & 24.00 & 10.85 & 42.78 & 18.95 \\
\hline & 7 & \multirow{2}{*}{ Drohiczyn } & before & 7.02 & 10.80 & 11.18 & 16.83 & 10.80 \\
\hline & 8 & & behind & 6.77 & 12.00 & 11.50 & 21.99 & 12.45 \\
\hline \multirow{2}{*}{ Kamianka } & 9 & \multirow{2}{*}{ Siemiatycze } & before & 6.94 & 15.60 & 13.47 & 23.09 & 12.95 \\
\hline & 10 & & behind & 6.53 & 18.40 & 14.63 & 41.73 & 18.80 \\
\hline \multicolumn{9}{|c|}{ Principal statistical data } \\
\hline \multicolumn{5}{|c|}{ Mean \pm standard deviation } & 11.78 & $\begin{array}{c}11.87 \pm \\
1.38\end{array}$ & $\begin{array}{c}28.05 \pm \\
10.85\end{array}$ & $\begin{array}{c}15.30 \pm \\
3.45\end{array}$ \\
\hline \multicolumn{5}{|l|}{ Median } & 11.40 & 11.34 & 23.13 & 14.28 \\
\hline \multicolumn{4}{|l|}{ Minimum } & 6.53 & 1.40 & 10.45 & 16.83 & 10.80 \\
\hline \multicolumn{4}{|l|}{ Maximum } & 7.36 & 24.00 & 14.63 & 45.12 & 21.10 \\
\hline \multicolumn{6}{|c|}{ Geochemical background } & $20^{*}, 10^{* *}$ & $95^{*}, 48^{* *}$ & $68^{*}, 5^{* *}$ \\
\hline
\end{tabular}

* According to Turekian \& Wedephol (1961).

** According to Bojakowska \& Sokołowska (1998). 
The contents of lead, zinc, and nickel in the bottom sediments of the Bug and Kamianka rivers are presented in Table 3. The average content of analyzed metals from measurement points 1 , $3,5,8,9$ located before the treatment plant was: $\mathrm{Pb}-11.54 ; \mathrm{Zn}-21.81 ; \mathrm{Ni}-13.74 \mathrm{mg} \cdot \mathrm{kg}^{-1}$. After the discharge of purified wastewater, quantities of studied metals increased: $\mathrm{Pb}-12.18$; $\mathrm{Zn}-34.28$; $\mathrm{Ni}-16.85 \mathrm{mg} \cdot \mathrm{kg}^{-1}$ in bottom sediments at sampling points $2,4,6,7,10$. The study reveals that the largest concentrations of zinc and nickel were introduced by the treatment plant in Włodawa. At measurement point 1 after this plant, the zinc content was $45.12 \mathrm{mg} \cdot \mathrm{kg}^{-1}$, while nickel was $21.10 \mathrm{mg} \cdot \mathrm{kg}^{-1}$. The machinery, tanning, and meat industry factories also deliver wastewater to the municipal sewage treatment plant in Włodawa. The largest contents of lead $\left(14.63 \mathrm{mg} \cdot \mathrm{kg}^{-1}\right)$ were recorded below the treated wastewater discharge on the Kamianka River, into which sewage from the treatment plant in Siemiatycze is discharged. Among the sewage treatment plants analyzed, those in Włodawa and Siemiatycze are characterized by the highest amounts of discharged wastewater to the receivers. The most frequently seen ranges of $\mathrm{Pb}, \mathrm{Zn}$ and Ni concentrations in raw and treated city sewages were shown in Table 4 .

The chemical composition of bottom sediments in rivers is greatly affected by the geological structure and soil cover of the catchment. The content of metals in sediments can also result from the geo-chemical nature of a given element or bottom sediment properties. Nevertheless, the largest quantity of metals occurs in bottom sediments in proximity to contamination sources and this was reflected in our findings. It should also be stated that metals present in a river can be transported in the form of a suspension with an organic substance or with loamy fractions. Their mobility within the environment is enhanced due to $\mathrm{pH}$ or redox potential change, thus constituting both a potential and real threat to an aquatic ecosystem.

The geochemical atlas of Poland (Lis \& Pasieczna 1995) indicates that the arithmetic mean for the studied Polish rivers is: $68 \mathrm{mg} \cdot \mathrm{kg}^{-1}$ for lead, $247 \mathrm{mg} \cdot \mathrm{kg}^{-1}$ for zinc, whereas much lower values were obtained for them in the present study, while in the case of nickel it was higher. According to the classification by Bojakowska \& Sokołowska (1998), all of the studied sediments were considered uncontaminated. When analyzing the geo-accumulation index (Tab. 5) for all of the studied metals $(\mathrm{Pb}, \mathrm{Zn}, \mathrm{Ni})$, which for $100 \%$ of bottom sediment samples reached negative value, it is clear that, according to the classification, these sediments can be qualified as uncontaminated (class 0 ).

Table 4

$\mathrm{Pb}, \mathrm{Zn}$ and Ni concentrations in city and municipal wastewater

\begin{tabular}{|c|c|c|c|c|c|c|}
\hline \multirow{3}{*}{ References } & \multicolumn{2}{|c|}{$\mathbf{P b}$} & \multicolumn{2}{|c|}{$\mathrm{Zn}$} & \multicolumn{2}{|c|}{$\mathbf{N i}$} \\
\hline & $\begin{array}{c}\text { raw } \\
\text { wastewater }\end{array}$ & $\begin{array}{c}\text { treated } \\
\text { wastewater }\end{array}$ & $\begin{array}{c}\text { raw } \\
\text { wastewater }\end{array}$ & $\begin{array}{c}\text { treated } \\
\text { wastewater }\end{array}$ & $\begin{array}{c}\text { raw } \\
\text { wastewater }\end{array}$ & $\begin{array}{c}\text { treated } \\
\text { wastewater }\end{array}$ \\
\hline & \multicolumn{6}{|c|}{$\left[\mathbf{m g} \cdot \mathbf{d m}^{-3}\right]$} \\
\hline $\begin{array}{l}\text { Dusza \& Zabłocki } \\
(2009)\end{array}$ & no data & no data & no data & no data & $\begin{array}{l}0.001-0.061 \\
\text { mean } 0.005\end{array}$ & $\begin{array}{c}0.0004-0.024 \\
\text { mean } 0.002\end{array}$ \\
\hline $\begin{array}{l}\text { Cyprowski \& Krajewski } \\
\text { (2003) }\end{array}$ & $0.1-13.0$ & $0.08-10.4$ & $\begin{array}{l}0.1-133.0 \\
\text { mean } 0.65\end{array}$ & $\begin{array}{l}0.06-79.8 \\
\text { mean } 0.39\end{array}$ & $\begin{array}{l}0.04-7.30 \\
\text { mean } 0.067\end{array}$ & $\begin{array}{l}0.016-2.92 \\
\text { mean } 0.027\end{array}$ \\
\hline Yadav et. al (2002) & 0.19 & 0.15 & 0.07 & 0.04 & 0.12 & 0.05 \\
\hline $\begin{array}{l}\text { Own, original, } \\
\text { unpublished data }\end{array}$ & 0.20 & 0.19 & 0.33 & 0.15 & 0.10 & 0.09 \\
\hline $\begin{array}{l}\text { Highest acceptable } \\
\text { metal concentrations in } \\
\text { discharged wastewater } \\
\text { (Rozporządzenie 2014) }\end{array}$ & \multicolumn{2}{|c|}{0.5} & \multicolumn{2}{|c|}{2.0} & \multicolumn{2}{|c|}{0.5} \\
\hline
\end{tabular}


Table 5

Values of the $I_{\text {geo }}$ coefficient

\begin{tabular}{|c|c|c|c|c|c|c|}
\hline \multirow{2}{*}{ River } & \multicolumn{3}{|c|}{ Measurement points } & \multicolumn{3}{|c|}{$I_{g e o}$} \\
\hline & & & & $\mathbf{P b}$ & $\mathrm{Zn}$ & $\mathrm{Ni}$ \\
\hline \multirow{8}{*}{ Bug } & 1 & \multirow{2}{*}{ Włodawa } & before & -1.47 & -2.62 & -2.61 \\
\hline & 2 & & behind & -1.46 & -1.66 & -2.27 \\
\hline & 3 & \multirow{2}{*}{ Terespol } & before & -1.35 & -2.92 & -3.01 \\
\hline & 4 & & behind & -1.20 & -2.85 & -2.98 \\
\hline & 5 & \multirow{2}{*}{ Mielnik } & before & -1.52 & -2.39 & -2.71 \\
\hline & 6 & & behind & -1.47 & -1.74 & -2.43 \\
\hline & 7 & \multirow{2}{*}{ Drohiczyn } & before & -1.42 & -3.08 & -3.24 \\
\hline & 8 & & behind & -1.38 & -2.70 & -3.03 \\
\hline \multirow{2}{*}{ Kamianka } & 9 & \multirow{2}{*}{ Siemiatycze } & before & -1.16 & -2.63 & -2.98 \\
\hline & 10 & & behind & -1.04 & -1.77 & -2.44 \\
\hline
\end{tabular}

Similar dependencies were recorded by Jeelani et al. (2017) on the Suoxu River in China, to which wastewater from treatment plants is discharged: the total metal concentration was $\mathrm{Pb}-15.2 \pm 27.3$, $\mathrm{Zn}-35 \pm 156, \mathrm{Ni}-15.3 \pm 41 \mathrm{mg} \mathrm{kg}^{-1}$. In comparison with the contents of the studied elements in the bottom sediments from the Bug and Kamianka Rivers, similar or higher metal contents were recorded in Europe and Asia (Tab. 6), which oscillated within $\left[\mathrm{mg}^{-\mathrm{kg}^{-1}}\right]$ : $21.11-128(\mathrm{~Pb}), 63.84-$ $261.74(\mathrm{Zn}), 31.80-106.00(\mathrm{Ni})$.

The subject of study also consisted of three species of aquatic plants: Acorus calamus L., Nuphar lutea L., Typha angustifolia L. Aquatic species reflect heavy metal contents in the natural environment and are a complement of bottom sediment studies (Skorbiłowicz 2014). Contents of lead, zinc, and nickel in individual parts of macrophytes varied (Tab. 7). Average concentrations of analyzed metals from measurement points 1, 3, 5, 8, 9 located before the treatment plant were: for $\mathrm{Pb}-10.60 \mathrm{mg} \cdot \mathrm{kg}^{-1}$ (root), $9.98 \mathrm{mg} \cdot \mathrm{kg}^{-1}$ (stem), $10.05 \mathrm{mg} \cdot \mathrm{kg}^{-1}$ (leaf), $\mathrm{Zn} \mathrm{-} 38.30 \mathrm{mg} \cdot \mathrm{kg}^{-1}$ (root), $24.06 \mathrm{mg} \cdot \mathrm{kg}^{-1}$ (stem), $28.14 \mathrm{mg} \cdot \mathrm{kg}^{-1}$ (leaf), $\mathrm{Ni}-9.02 \mathrm{mg} \cdot \mathrm{kg}^{-1}$ (root), $4.86 \mathrm{mg} \cdot \mathrm{kg}^{-1}$ (stem), $8.96 \mathrm{mg} \cdot \mathrm{kg}^{-1}$ (leaf) $\mathrm{mg} \cdot \mathrm{kg}^{-1}$. After the discharge of treated wastewater, quantities of studied metals increased: $\mathrm{Pb}-11.17 \mathrm{mg} \cdot \mathrm{kg}^{-1}$ (root), $10.90 \mathrm{mg} \cdot \mathrm{kg}^{-1}$ (stem), $10.74 \mathrm{mg} \cdot \mathrm{kg}^{-1}$ (leaf) $\mathrm{Zn} \mathrm{-} 44.59 \mathrm{mg} \cdot \mathrm{kg}^{-1}$ (root), $36.93 \mathrm{mg} \cdot \mathrm{kg}^{-1}$ (stem), $34.92 \mathrm{mg} \cdot \mathrm{kg}^{-1}$ (leaf), $\mathrm{Ni}-11.29 \mathrm{mg} \cdot \mathrm{kg}^{-1}$ (root), $8.48 \mathrm{mg} \cdot \mathrm{kg}^{-1}$ (stem), $11.71 \mathrm{mg} \cdot \mathrm{kg}^{-1}$ (leaf), in sampling points $2,4,6,7,10$. The plant material confirmed that sewage treatment plants affect the increase in metal contents in the aquatic environment of rivers.

Table 6

Comparison of heavy metal content in bottom sediments for other world rivers

\begin{tabular}{|c|c|c|c|c|}
\hline \multirow{2}{*}{ Study object } & \multicolumn{3}{|c|}{ Mean content \pm SD $\left[\mathrm{mg} \cdot \mathrm{kg}^{-1}\right]$} & \multirow{2}{*}{ References } \\
\hline & $\mathrm{Pb}$ & $\mathrm{Zn}$ & $\mathrm{Ni}$ & \\
\hline Bug and Kamianka rivers & $11.87 \pm 1.38$ & $28.05 \pm 10.85$ & $15.30 \pm 3.45$ & this study \\
\hline Polish rivers & 68.00 & 247.00 & 11.00 & Lis \& Pasieczna (1995) \\
\hline Luan River, China & $22.11 \pm 10.96$ & $75.52 \pm 46.21$ & NT & Liu et al. (2009) \\
\hline Gediz River,Turkey & $128.00 \pm 15.00$ & $160.00 \pm 15.00$ & $106.00 \pm 10.00$ & Akcay et al. (2003) \\
\hline Almendares River, Cuba & $92.58 \pm 43.26$ & $261.74 \pm 157.14$ & NT & Olivares-Rieumont et al. (2005) \\
\hline \multirow{2}{*}{ Yangtze River, China } & $47.13 \pm 21.98$ & $255.00 \pm 288.05$ & $43.31 \pm 8.95$ & Yang et al. (2008) \\
\hline & $27.30 \pm 5.60$ & $94.30 \pm 23.90$ & $31.80 \pm 7.20$ & Zhang et al. (2009) \\
\hline Kali River, India & 32.16 & 63.84 & NT & Maurya \& Malik. (2016) \\
\hline Mahandi River, India & 123.00 & 117.00 & 47.00 & Sundaray et al. (2011) \\
\hline
\end{tabular}




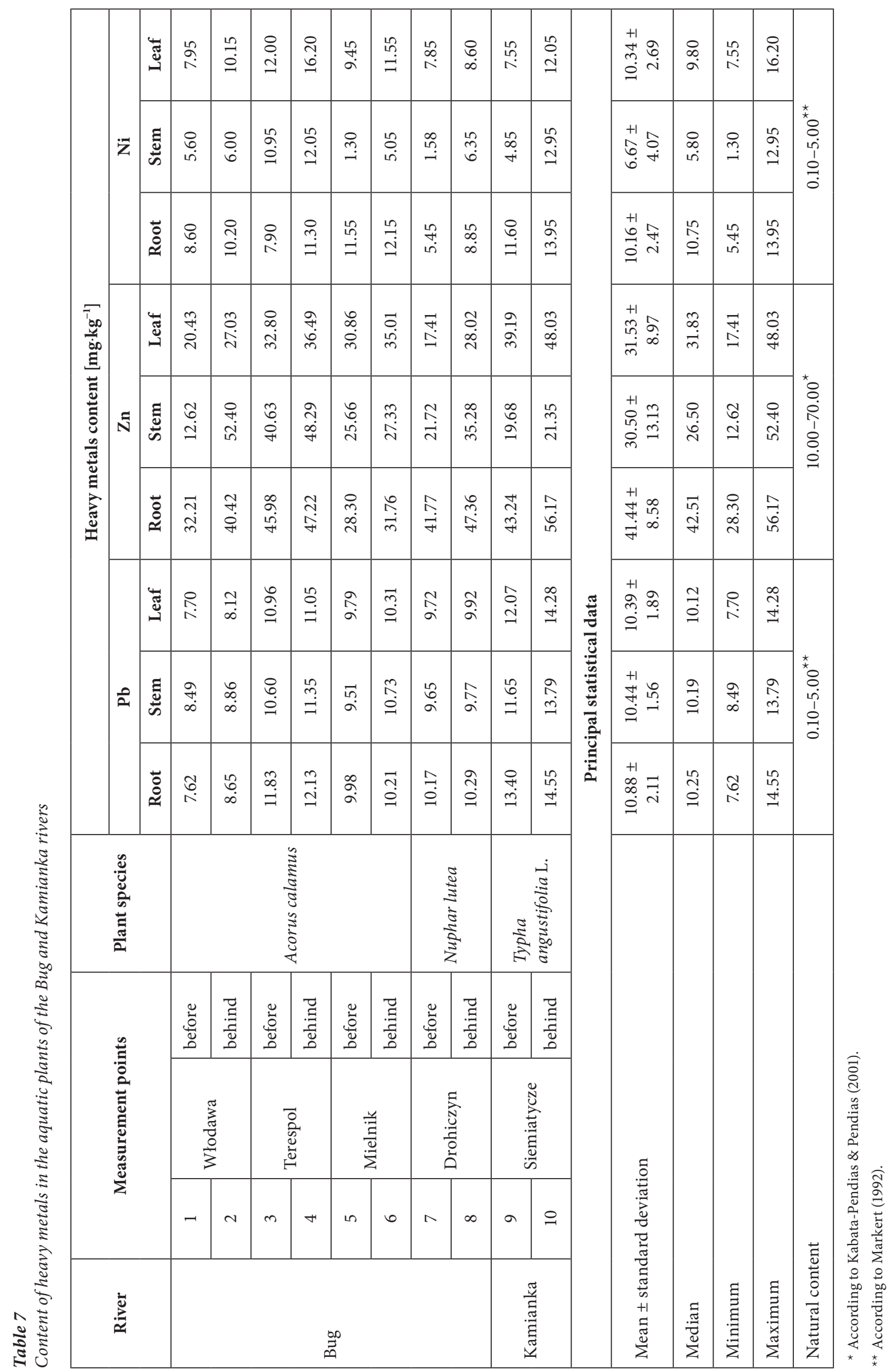




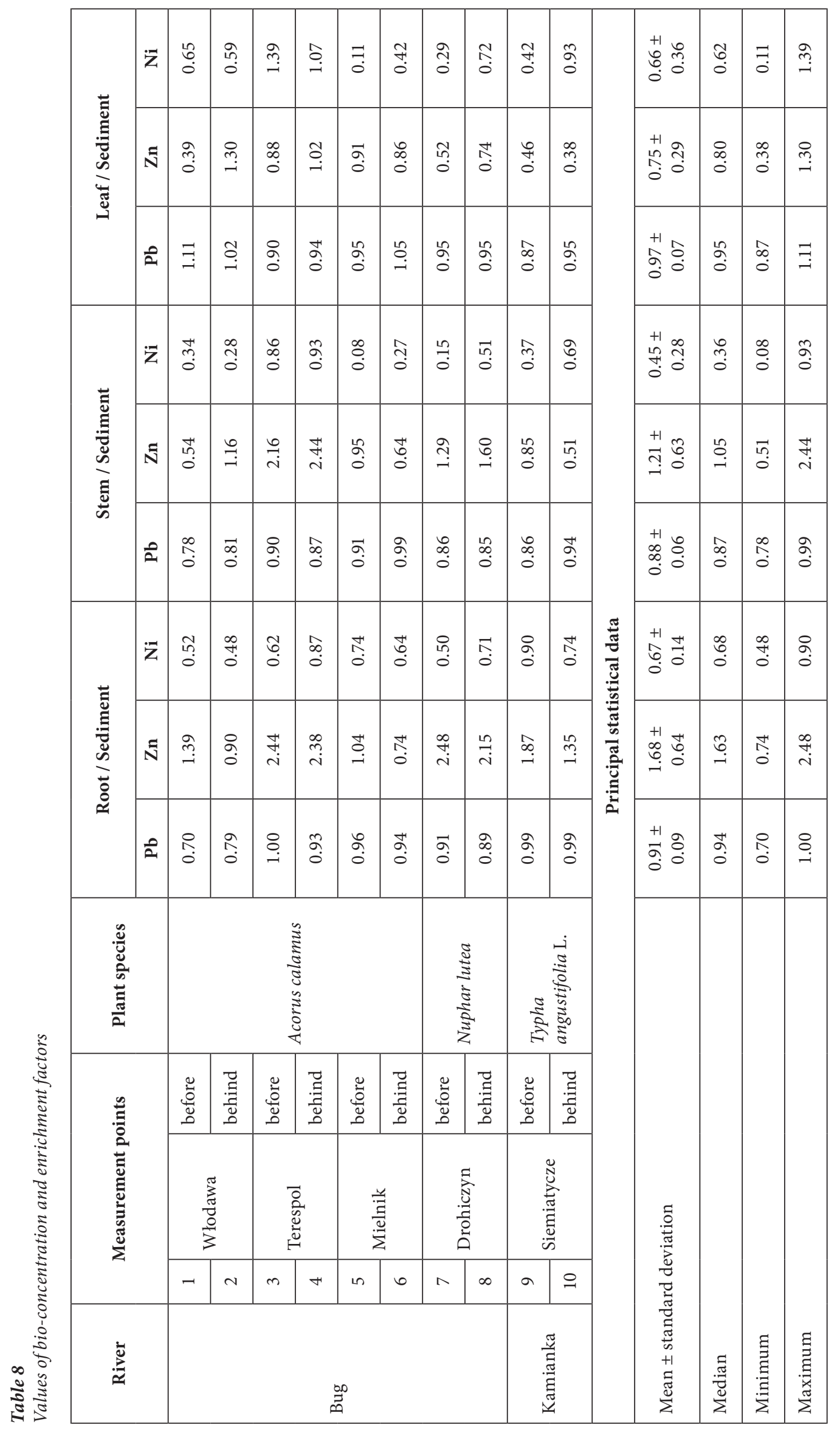


The study revealed that the largest concentrations of lead, zinc, and nickel are introduced by the sewage treatment plant in Siemiatycze. At measurement point 10 below that plant, the highest contents of analyzed metals were recorded, with the exception of zinc in stem. The study also showed higher levels of analyzed metals in plant roots than in stems or leaves for most cases and especially visible for zinc. Cardwell et al. (2002) also reported the differentiation of zinc distribution over a plant; in general, the highest zinc contents occurred in roots, while it was lower in stems and leaves. Zinc is an element that is necessary for the functioning of plants but in excess it can be harmful. Higher zinc concentrations in roots may also point to the protective barrier that limits the transport of excessive amount of zinc to stem and leaves. Achieved results from plant material analyses indicate the absence of aquatic environment contamination with this element (Kabata-Pendias \& Pendias 1999). The lead results in test plant species did not exceed the toxic level of $30 \mathrm{mg} \cdot \mathrm{kg}^{-1}$, but they were not within the range of natural values (Kabata-Pendias \& Pendias 1999). Lead is a very widespread element in the environment. According to Ali et al. (2004) and Liu et al. (2008), lead is a very toxic metal that affects the growth and development of plants. Nickel, in low doses, is necessary for the appropriate functioning of plants (Jeelani et al. 2017). The results achieved from the analyses of plant material showed a slight contamination of the aquatic environment due to nickel. The contents of studied metals varied in roots, stems, and leaves in a sequence $\mathrm{Zn}>\mathrm{Pb}>\mathrm{Ni}$. In order to compare the contents of lead, zinc, and nickel in bottom sediments as well as in roots, stems, and leaves of test aquatic plant species, the bio-concentration factor (BCF) and enrichment coefficient (BF) were used (Tab. 8). In terms of root-sediment, average values of the coefficient were: $\mathrm{Pb}$ (0.91); $\mathrm{Zn}(1.68)$ and $\mathrm{Ni}(0.67)$. Slightly lower average values of the coefficient were recorded for the relation between stem-sediment $(\mathrm{Pb}-0.88 ; \mathrm{Zn}-1.21 ; \mathrm{Ni}-0.45)$ and leaf-sediment $(\mathrm{Pb}-0.97 ; \mathrm{Zn}-0.75 ; \mathrm{Ni}-0.66)$. Table 9 presents the results of aquatic plant tests from Poland and Argentina - contents of lead and nickel in both cases were on comparable levels, while in the case of zinc, its amount was clearly lower in the studied sections of the Bug and Kamianka rivers in relation to examples from Argentina and Poland. It is noteworthy that in the presented list, both the highest (the Piława River) and the lowest (the Bug and Kamianka rivers) values for zinc were recorded in Poland.

Table 9

Comparison of heavy metal content in macrophytes for other world rivers

\begin{tabular}{|c|c|c|c|c|c|}
\hline \multirow{2}{*}{ Study object } & \multirow{2}{*}{ Plant species } & \multicolumn{3}{|c|}{ Mean content \pm SD $\left[\mathrm{mg} \cdot \mathrm{kg}^{-1}\right]$} & \multirow{2}{*}{ References } \\
\hline & & $\mathbf{P b}$ & $\mathrm{Zn}$ & $\mathrm{Ni}$ & \\
\hline Bug and Kamianka rivers & $\begin{array}{l}\text { Acorus calamus, } \\
\text { Nuphar lutea, Typha } \\
\text { angustifolia L. }\end{array}$ & $10.57 \pm 1.78$ & $34.49 \pm 11.06$ & $9.05 \pm 3.44$ & this study \\
\hline $\begin{array}{l}\text { Suquía River, Argentina } \\
\text { (2006) }\end{array}$ & \multirow{2}{*}{ Stuckenia filiformis } & $7.92 \pm 4.30$ & $52.5 \pm 47.8$ & $5.68 \pm 5.26$ & \multirow{2}{*}{$\begin{array}{l}\text { Harguinteguy } \\
\text { et al. (2014) }\end{array}$} \\
\hline $\begin{array}{l}\text { Suquía River, Argentina } \\
\text { (2009) }\end{array}$ & & $8.26 \pm 4.48$ & $60.0 \pm 42.6$ & $9.30 \pm 4.82$ & \\
\hline $\begin{array}{l}\text { Xanaes River, Córdoba, } \\
\text { Argentina }\end{array}$ & $\begin{array}{l}\text { Myriophyllum } \\
\text { aquaticum }\end{array}$ & $2.00 \pm 0.80$ & $87.00 \pm 84.00$ & $14.00 \pm 8.70$ & $\begin{array}{l}\text { Harguinteguy } \\
\text { et al. (2013) }\end{array}$ \\
\hline \multirow[b]{2}{*}{ Olobok River, Poland } & Elodea canadensis & $6.20 \pm 3.40$ & $255.00 \pm 34.00$ & $6.60 \pm 2.10$ & \multirow{4}{*}{$\begin{array}{c}\text { Samecka- } \\
\text { Cymerman \& } \\
\text { Kempers (2007) }\end{array}$} \\
\hline & $\begin{array}{l}\text { Potamogeton } \\
\text { crispus }\end{array}$ & $6.80 \pm 0.10$ & $278.00 \pm 1.50$ & $8.50 \pm 0.10$ & \\
\hline \multirow{2}{*}{ Piława River, Poland } & Elodea canadensis & $23.00 \pm 6.80$ & $304.00 \pm 58.00$ & $21.40 \pm 6.50$ & \\
\hline & $\begin{array}{l}\text { Potamogeton } \\
\text { crispus }\end{array}$ & $21.00 \pm 6.20$ & $293.00 \pm 58.00$ & $22.00 \pm 5.60$ & \\
\hline
\end{tabular}


Statistical analysis was performed between the studied indicators in bottom sediments and aquatic plants (Tab. 10), which showed the correlation of $\mathrm{Zn}$ and $\mathrm{Ni}$ in the organic matter content of the bottom sediments of the studied rivers. This is confirmed by correlation coefficients $(r)$ of 0.46 ; 0.30 , respectively, at $p \leq 0.05$. The correlation is caused by the specific properties of organic colloids, which are natural sorbents of heavy metals in the environment (Migaszewski \& Gałuszka 2007). Statistical calculations also showed a strong relationship between $\mathrm{Zn}$ and $\mathrm{Ni}$ content in sediments as confirmed by the correlation coefficient $r=0.94$ at $p \leq 0.05$. Enrichment of sediments with an organic substance is always accompanied by its enrichment with other components, including heavy metals. The described relationships allow us to state that the main source of organic matter in bottom sediments and related metals are treated wastewater discharged by the sewage treatment plants analyzed during fluctuations in their necessary degree of purification. In the sampling sites, no other sources of tested components were found except sewage discharge. The high variability of the chemical composition of the flowing water of sewage receivers does not allow us to clearly determine the impact of discharging treated wastewater on the aquatic environment as opposed to the much less variable composition of bottom sediments and macrophytes.

Statistical calculations also showed strong relationships between $\mathrm{Pb}$ content in bottom sediments and macrophyte roots and their individual organs: bottom sediment - root $(r=0.90)$, bottom sediment - stem $(r=0.91)$, bottom sediment - leaf $(r=0.88)$. This strong correlation is caused by the specific properties of organic colloids which are natural sorbents of heavy metals in the environment (Migaszewski \& Gałuszka, 2007). One was also found in the $\mathrm{Pb}$ content of the macrophytes themselves: root - stem $(r=0.95)$, root - leaf $(r=0.98)$ and stem - leaf $(r=0.98)$. In the case of $\mathrm{Zn}$, there was only a moderate correlation between bottom sediment - leaf $(r=0.40)$, root - leaf $(r=0.50)$. On the other hand, a slightly stronger correlation occurred in the case of Ni bottom sediment - root $(r=0.57)$, root - stem $(r=0.36)$, root - leaf $(r=0.41)$ and a strong dependence between stem leaf $(r=0.74)$.

\section{Table 10}

Relations between tested indicators in bottom sediments and aquatic plants

\begin{tabular}{|c|c|c|c|c|c|c|c|c|c|c|c|c|c|c|}
\hline Indicator & $\begin{array}{c}\text { pH } \\
\text { sedi- } \\
\text { ment }\end{array}$ & $\begin{array}{l}\text { OM } \\
\text { sedi- } \\
\text { ment }\end{array}$ & $\begin{array}{c}\mathrm{Pb} \\
\text { sedi- } \\
\text { ment }\end{array}$ & $\begin{array}{c}\text { Zn } \\
\text { sedi- } \\
\text { ment }\end{array}$ & $\begin{array}{c}\mathrm{Ni} \\
\text { sedi- } \\
\text { ment }\end{array}$ & $\begin{array}{c}\text { Root } \\
\text { Pb }\end{array}$ & $\begin{array}{c}\text { Stem } \\
\text { Pb }\end{array}$ & $\begin{array}{l}\text { Leaf } \\
\mathrm{Pb}\end{array}$ & $\begin{array}{c}\text { Root } \\
\text { Zn }\end{array}$ & $\begin{array}{c}\text { Stem } \\
\text { Zn }\end{array}$ & $\begin{array}{c}\text { Leaf } \\
\mathrm{Zn}\end{array}$ & $\begin{array}{c}\text { Root } \\
\mathrm{Ni}\end{array}$ & $\begin{array}{c}\text { Stem } \\
\mathrm{Ni}\end{array}$ & $\begin{array}{c}\text { Leaf } \\
\mathrm{Ni}\end{array}$ \\
\hline pH sediment & 1 & -033 & -0.53 & -0.56 & -0.39 & -0.34 & -0.52 & 0.42 & -0.50 & 0.03 & 0.45 & -0.52 & -0.33 & 0.16 \\
\hline OM sediment & -0.33 & 1 & -0.01 & 0.46 & 0.30 & 0.17 & 0.28 & 0.30 & -0.31 & -0.52 & 0.33 & 0.52 & -0.41 & 0.27 \\
\hline $\mathrm{Pb}$ sediment & -0.53 & -0.01 & 1 & 0.05 & -0.08 & 0.90 & 0.91 & 0.88 & 0.81 & -0.06 & 0.79 & 0.51 & 0.69 & 0.36 \\
\hline Zn sediment & -0.56 & 0.46 & 0.05 & 1 & 0.94 & 0 & 0.21 & 0.10 & -0.05 & 0.14 & 0.39 & 0.63 & 0.11 & 0.15 \\
\hline Ni sediment & -0.39 & 0.30 & -0.08 & 0.94 & 1 & -0.21 & 0.02 & 0.11 & -0.20 & 0.10 & 0.25 & 0.57 & 0.11 & 0.12 \\
\hline Root $\mathrm{Pb}$ & -0.34 & 0.17 & 0.90 & 0 & -0.21 & 1 & 0.95 & 0.98 & 0.72 & -0.04 & 0.84 & 0.50 & 0.57 & 0.38 \\
\hline Stem $\mathrm{Pb}$ & .52 & 0.28 & 0.91 & 0.21 & 0.02 & 0.95 & 1 & 0.98 & 0.68 & -0.10 & 0.90 & 0.63 & 0.64 & 0.46 \\
\hline Leaf $\mathrm{Pb}$ & -0.42 & 0.30 & 0.88 & 0.10 & -0.11 & 0.98 & 0.98 & 1 & 0.68 & -0.14 & 0.87 & 0.56 & 0.56 & 0.36 \\
\hline Root Zn & -0.50 & -0.31 & 0.81 & -0.05 & -0.20 & 0.72 & 0.68 & 0.68 & 1 & 0.25 & 0.50 & 0.12 & 0.74 & 0.35 \\
\hline Stem $\mathrm{Zn}$ & 0.03 & -0.52 & -0.06 & 0.14 & 0.10 & -0.04 & -0.10 & 0.14 & 0.25 & 1 & 0.06 & -0.01 & 0.37 & 0.59 \\
\hline Leaf Zn & -0.45 & 0.33 & 0.79 & 0.39 & 0.25 & 0.84 & 0.90 & 0.87 & 0.50 & 0.06 & 1 & 0.85 & 0.63 & 0.51 \\
\hline Root Ni & -0.52 & 0.52 & 0.51 & 0.63 & 0.57 & 0.50 & 0.63 & 0.56 & 0.12 & -0.01 & 0.85 & 1 & 0.36 & 0.41 \\
\hline Stem Ni & -0.33 & -0.41 & 0.69 & 0.11 & 0.11 & 0.57 & 0.64 & 0.56 & 0.74 & 0.37 & 0.63 & 0.36 & 1 & 0.74 \\
\hline Leaf $\mathrm{Ni}$ & -0.16 & -0.27 & 0.36 & 0.15 & 0.12 & 0.38 & 0.46 & 0.36 & 0.35 & 0.59 & 0.51 & 0.41 & 0.74 & 1 \\
\hline
\end{tabular}


During the conducted analyzes, it was verified whether there was a correlation of the content of studied metals in bottom sediments and macrophytes on the amount of wastewater discharged (Tab. 11). Spearman's rank order correlations were used for analyzes and the following correlations were obtained: amount of sewage discharged-organic substance ( 0.90$)$, Zn sediment ( 0.70$)$, Ni sediment (0.60), Ni root $(0.60)$. It turned out that the amount of discharged sewage may primarily affect the organic matter in bottom sediments and then the content of $\mathrm{Zn}$ and $\mathrm{Ni}$ in them.

Table 11

Relations between the tested indicators in sediments and aquatic plants vs. amount of sewage

\begin{tabular}{|l|c|}
\hline \multicolumn{1}{|c|}{ Indicator } & Sewage amount \\
\hline $\mathrm{pH}$ sediment & -0.10 \\
\hline OM sediment & 0.90 \\
\hline $\mathrm{Pb}$ sediment & -0.90 \\
\hline $\mathrm{Zn}$ sediment & 0.70 \\
\hline Ni sediment & 0.60 \\
\hline Root $\mathrm{Pb}$ & -0.60 \\
\hline Stem $\mathrm{Pb}$ & -0.60 \\
\hline Leaf $\mathrm{Pb}$ & -0.60 \\
\hline Root $\mathrm{Zn}$ & -0.90 \\
\hline Stem $\mathrm{Zn}$ & -0.50 \\
\hline Leaf $\mathrm{Zn}$ & -0.60 \\
\hline Root $\mathrm{Ni}$ & 0.60 \\
\hline Stem $\mathrm{Ni}$ & -0.90 \\
\hline Leaf $\mathrm{Ni}$ & -0.80 \\
\hline
\end{tabular}

\section{CONCLUSIONS}

In the bottom sediments and aquatic plants of the Bug and Kamianka rivers, a higher content of lead, zinc and nickel was found after the discharge of treated sewage in relation to their content before discharge but this did not constitute a threat to the aquatic environment of the watercourses studied.

The content of the organic substance behind the discharge of treated wastewater was higher in relation to its content before the discharge, which indicates the accumulation of organic matter in bottom sediments, the source of which may not always be well-treated wastewater. At all of the tested points, the $\mathrm{pH}$ of sediments after the discharge of treated wastewater was lower, which indicates the effect of treated wastewater on the river aquatic environment in the absence of other disturbing emissions. The study showed the correlation of $\mathrm{Zn}$ and $\mathrm{Ni}$ content in bottom sediments to the organic matter content in them, which is rather typical due to the natural properties of organic matter.

As a result of the research data analysis, the strong correlation of $\mathrm{Pb}$ content in the individual organs of the tested macrophytes on its content in bottom sediments was demonstrated. Therefore, the thesis was confirmed that macrophytes are a good bioindicator of the aquatic environment in the case of $\mathrm{Pb}$ studies. Statistical analysis showed that the amount of sewage discharged into the tested receivers influenced the content of organic matter, zinc and nickel in bottom sediments.

\section{REFERENCES}

Akcay H., Oguz A. \& Karapire C., 2003. Study of heavy metal pollution and speciation in Buyak Menderes and Gediz river sediments. Water Research, 37(4), 813-22.

Albers P.H. \& Camardese M.B., 1993. Effects of acidification on metal accumulation by aquatic plants and invertebrates. 1. Constructed wetlands. Environmental Toxicology and Chemistry, 12, 6, 959-967.

Ali N.A., Bernal M.P. \& Ater M., 2004. Tolerance and bioaccumulation of cadmium by Phragmitesaustralis grown in the presence of elevated concentrations of cadmium, copper, and zinc. Aquatic Botany, 80, 163-176.

Banach M. \& Chlost I., 2005. Zbiornik Krzynia jako basen sedymentacyjny rzeki Słupi. [in:] Kotarba A., Krzemień K. \& Święchowicz I. (red.), Wspótczesna ewolucja rzeźby Polski: VII Zjazd Geomorfologów Polskich, Kraków, 19-22 września 2005, Instytut Geografii i Gospodarki Przestrzennej Uniwersytetu Jagiellońskiego, Kraków, 27-32.

Banerjee U.S. \& Gupta S., 2013. Impact of industrial waste effluents on River Damodar adjacent to Durgapur industrial complex, West Bengal, India. Environmental Monitoring and Assessment, 185, 2083-2094.

Bielski A., 2012. Wpływ zrzutu nieoczyszczonych ścieków na środowisko wodne cieku. Inżynieria i Ochrona Środowiska, 15, 2, 119-142.

Bojakowska I. \& Sokołowska G., 1998. Charakterystyka geochemiczna aluwiów głównych rzek Polski. Przegląd Geologiczny, 1, 16-20.

Bojakowska I., 2001. Kryteria oceny zanieczyszczenia osadów wodnych. Przegląd Geologiczny, 49, 3, 213-218.

Brack K., Johannesson L. \& Stevens R., 2001. Accumulation rates and mass calculations of $\mathrm{Zn}$ and $\mathrm{Hg}$ in recent sediments, Götaälv estuary, Sweden. Environmental Geology, 40, 1232-1241.

Cardwell A.J., Hawker D.W. \& Greenway M., 2002. Metal accumulation in aquatic macrophytes from southeast Queensland, Australia. Chemosphere, 48, 653-663. 
Ciszewski D. \& Aleksander-Kwaterczak U., 2015. Zanieczyszczenie osadów metalami: transport, akumulacja, remobilizacja, remediacja. Wydawnictwa AGH, Kraków, 1-165.

Cyprowski M. \& Krajewski J., 2003. Czynniki szkodliwe dla zdrowia występujące w oczyszczalniach ścieków komunalnych. Medycyna Pracy, 54, 1, 73.

Djingova R., Kuleff I. \& Markert B., 2004. Chemical fingerprinting of plants. Ecological Research, 19, 1, 3-11. DOI: 10.1111/j.1440-1703.2003.00602.x.

Donahue R., Hendry M. \& Landini P., 2000. Distribution of arsenic and nickel in uraniom mill tailings, Rabbit Lake, Saskatchewan, Canada. Applied Geochemistry, 15, 1097-1119. DOI: 10.1016/S0883-2927(99)00114-6.

Dou Y., Li J., Zhao J., Hu B. \& Yang S., 2013. Distribution, enrichment and source of heavy metals in surface sediments of the eastern Beibu Bay, South China Sea. Marine Pollution Bulletin, 67, 1, 137-145.

Dusza E. \& Zabłocki Z., 2009. Zmienność zawartości miedzi i niklu w ściekach surowych z miejskiej oczyszczalni ścieków w Reczu. Zeszyty Problemowe Postępów Nauk Rolniczych, 540, 329-336.

Essien J.P., Antai S.P. \& Olajire A.A., 2009. Distribution, Seasonal Variations and Ecotoxicological Significance of Heavy Metals in Sediments of Cross River Estuary Mangrove Swamp. Water, Air, \& Soil Pollution, 197, 91-105. DOI: $10.1007 /$ s11270-008-9793-x

Förstner U. \& Wittmann G.T.W., 1981. Metal Pollution in the Aquatic Environment. Springer-Verlag, Berlin.

Harguinteguy C.A., Schreiber R. \& Pignata M.L., 2013. Myriophyllumaquaticum as a biomonitor of water heavy metal input related to agricultural activities in the Xanaes River (Cordoba, Argentina). Ecological Indicators, 27, 8-16.

Harguinteguy C.A., Fernandez Cirelli A. \& Pignata M.L., 2014. Heavy metal accumulation in leaves of aquatic plant Stuckeniafiliformis and its relationship with sedyment and water in the Suquia River (Argentina). Microchemical Journal, 114, 111-118.

Hu B., Li G., Li J., Bi J., Zhao J. \& Bu R., 2013. Spatial distribution and ecotoxicological risk assessment of heavy metals in surface sediments of the southern Bohai Bay, China. Environmental Science and Pollution Research, 20, 6, 4099-4110. DOI: 10.1007/s11356-012-1332-z.

Jeelani N., Zhu Z., Wang P., Zhang P., Song S., Yuan H., An S. \& Leng X., 2017. Assessment of Trace Metal Contamination and Accumulation in Sediment and Plants of the Suoxu River, China. Aquatic Botany, 140, 92-95.

Kabata-Pendias \& Pendias A., 1999. Biogeochemia pierwiastków śladowych. Wydawnictwo Naukowe PWN, Warszawa.

Klumpp A., Bauer K., Franz-Gerstein C. \& Menezes M., 2002. Varation of nutrient and metal concentration in aquatic macrophytes along the Rio Cachoeria in Bahia (Brazil). Environmental International, 28, 165-171.

Kucuksezgin F., Uluturhan E. \& Batki H., 2008. Distribution of heavy metals in water, particulate matterand sediments of Gediz River (Eastern Aegean). Environmental Monitoring and Assessment, 141, 213-225.

Lin Y.X., Zhang X.M., 1990. Accumulation of heavy metals and the variation of amino acids and protein in
Eichhorniacrassipes (Mart.) Solms in the Dianchi Lake. Oceanologia et Limnologia Sinica, 21, 179-184.

Lindström M., 2001a. Mercury in sediment and fish communities of Lake Vanern, Sweden: recovery from contamination. AMBIO: A Journal of the Human Environment, 30, 8, 538-544.

Lindström M., 2001b. Urban land use influences on heavy metals fluxes and surface sediment concentrations of small lakes. Water, Air, \& Soil Pollution, 126, 3-4, 363-383.

Lis J. \& Pasieczna A., 1995. Atlas geochemiczny Polski w skali 1: 2500 000. Państwowy Instytut Geologiczny, Warszawa.

Liu J.N., Zhou Q.X., Sun T., Ma L.Q. \& Wang S., 2008. Growth responses of three ornamental plants to $\mathrm{Cd}$ and $\mathrm{Cd}-\mathrm{Pb}$ stress and their metal accumulation characteristics. Journal of Hazardous Materials, 151, 261-267

Liu J., Li Y., Zhang B., Cao J., Cao Z. \& Domagalski J., 2009. Ecological risk of heavy metals in sediments of the Luan River source water. Ecotoxicology. 18, 748-758.

Markert B., 1992. Presence and significance of naturally occurring chemical elements of the periodic system in the plant organism and consequence for future investigations on inorganic environmental chemistry in ecosystems. Vegetatio, 103, 1, 1-30.

Mecray E.L., King J.W., Appleby P.G. \& Hunt A.S., 2001. Historical trace metal accumulation in the sediments of an urbanized region of the Lake Champlain Watershed, Burlington, Vermont. Water, Air \& Soil Pollution, 125, $1-4,201-230$.

Migaszewski Z.M. \& Gałuszka A., 2007. Podstawy geochemii środowiska. WNT, Warszawa.

Müller G., 1979. Schwermetalle in den sediments des Rheins-Veranderungenseitt 1971. Umschau, 79, 24, 778-783.

Nocoń W., 2006. Zawartość metali ciężkich w osadach dennych rzeki Kłodnicy. Instytut Podstaw inżynierii Środowiska w PAN w Zabrzu. Journal of Elementology, 11, 4, 457-466.

Olivares-Rieumont S., Rosa D., Lima L., Graham D.W., Alessandro K.D., Borroto J., Martinez F. \& Sanchez J., 2005. Assessment of heavy metal levels in Almendares River sediments - Havana City, Cuba. Water Research, 39, 3945-3953

Pradip K. Maurya D. \& Malik S., 2016. Distribution of heavy metals in water, sediments and fish tissue (Heteropneustisfossilis) in Kali River of western U.P. India. International Journal of Fisheries and Aquatic Studies, 4, 2, 208-215.

Raza A., Farooqi A., Javed A. \& Ali W., 2016. Distribution, enrichment, and Skurceidntification of selected heavy metals in surface sediments of the Siran River, Mansehra, Pakistan. Environmental Monitoring and Assessment, $188,572$.

Rozporządzenie, 2014. Rozporządzenie Ministra Środowiska $z$ dnia 18 listopada 2014 r. w sprawie warunków, jakie należy spetnić przy wprowadzaniu ścieków do wód lub do ziemi, oraz w sprawie substancji szczególnie szkodliwych dla środowiska wodnego. Dz.U. 2014, poz. 1800.

Rutherford J.C., 1994. River Mixing. John Wiley \& Sons, Chichester. 
Samecka-Cymerman A. \& Kempers A.J., 2007. Heavy Metals in Aquatic Macrophytes from Two Small Rivers Polluted by Urban, Agricultural and Textile Industry Sewages SW Poland. Archives of Environmental Contamination and Toxicology, 53, 2, 198-206.

Skorbiłowicz E., 2012. Studia nad rozmieszczeniem niektórych metali w środowisku wodnym zlewni górnej Narwi. Rozprawy Naukowe - Politechnika Białostocka, 222, Oficyna Wydawnicza Politechniki Białostockiej, Białystok.

Skorbiłowicz E., 2014. Macrophytes as indicators of heavy metals bio-accumulation in upper Narew River. Ecological Chemistry and Engineering. A, 21, 1, 87-98. DOI 10.2428/ecea.2014.21(1)9.

Skorbiłowicz M., Skorbiłowicz E., Wójtowicz P. \& Zamojska E., 2017. Determination of mixing zones for wastewater with receiver waters. Journal of Ecological Engineering, 18, 4, 192-198.

Sundaray K.S., Nayak B.B., Lin S. \& Bhatta D., 2011. Geochemical speciation and risk assessment of heavy metals in the River estuarine sediments - A case study: Mahanadi basin, India. Journal of Hazardous Materials, 186, 1837-1846.

Szoszkiewicz K., Jusik S. \& Zgoła T., 2010. Klucz do oznaczania makrofitów dla potrzeb oceny stanu ekologicznego wód powierzchniowych. Wyd. $2 \mathrm{zm}$. Biblioteka Monitoringu Środowiska, Inspekcja Ochrony Środowiska, Warszawa.
Tian S., Wang Z. \& Shang H., 2011. Study on the Self-purification of Juma River. Procedia Environmental Sciences, $11,1328-1333$.

Turekian K.K. \& Wedepohl K.H., 1961. Distribution of the Elements in some major units of the Earth's crust. Geological Society of America Bulletin, 72, 175-192.

Wang J., Liu R., Zhang P., Yu W., Shen Z. \& Feng C., 2014. Spatial variation, environment al assessment and source identification of heavy metals in sediments of the Yangtze River estuary. Marine Pollution Bulletin, 87, 364-373.

Xu Y., Sun Q., Yi L., Yin X., Wang A., Li Y. \& Chen J., 2014. The source of natural and anthropogenic heavy metals in the sediments of the Minjiang River estuary (SE China): implications for historical pollution. Science of the Total Environment, 493, 729-736.

Yadav R.K., Goyal B., Sharma R.K., Dubey S.K. \& Minhas P.S., 2002. Post-irrigation impact of domestic sewage effluent on composition of soils, crops and ground water A case study. Environment International, 28, 481-486.

Yang Z., Wang Y., Shen Z., Niu J. \& Tang Z., 2008. Distribution and speciation of heavy metals in sediments from the mainstream, tributaries, and lakes of the Yangze River catchment of Wuhan, China. Journal of Hazardous Materials, 166, 2-3, 1186-1194.

Zhang W., Feng H., Chang J., Qu J., Xie H. \& Yu L., 2009. Heavy metal contamination in surface sediments of Yangtze River intertidal zone: An assessment from different indexes. Environmental Pollution, 157, 1533-1543. 